Controlling the Public Wage Bill in Portugal:

The Case of University Professors

\author{
Alfredo M. Pereira \\ College of William and Mary \\ Rui Manuel Pereira \\ Universidade Nova de Lisboa
}

College of William and Mary

Department of Economics

Working Paper Number 36

July 2006, revised August 2006

The first draft of this paper was completed while the first author was a consultant and the second author was an intern with the Direç̧ão Geral de Estudos e Previsão, Ministério das Finanças, Portugal. Both authors would like to thank Manuel Ribeiro da Costa and Pedro Rodrigues for very useful comments and suggests. Of course all remaining errors are the exclusive responsibility of the authors. 
COLLEGE OF WILLIAM AND MARY

DEPARTMENT OF ECONOMICS

WORKING PAPER \# 36

July 2006, revised August 2006

\title{
Controlling the Public Wage Bill in Portugal: The Case of University Professors
}

\begin{abstract}
Public wages are a large share of the public budget in Portugal and, therefore, hiring freezes are a central feature of the efforts to control the public deficit. The system of public career advancement, however, may lead to increases in the wage bill even in the presence of hiring freezes. We estimate this wage drift effect in the case of university professors. We use a logit analysis with 1999 census data to identify the determinants of career advancement, to estimate the employment distribution in previous years, and to obtain the corresponding wage bill. We estimate that the annual wage drift is $2.6 \%$, a figure well above the GDP growth rate and, therefore, we conclude that hiring freezes may be far from enough to stop the expansion of the public wage bill.
\end{abstract}

JEL Codes: H60, J30, J45

Keywords: public wages, budgetary restraint.

Alfredo M. Pereira

Department of Economics

College of William and Mary

P.O. Box 8795

Williamsburg, VA 23187-8795

USA

ampere@wm.edu
Rui Manuel Pereira

Faculdade de Ciências e Tecnologia

Universidade Nova de Lisboa

Lisbon

Portugal

rmpereira770@yahoo.com 


\section{Introduction}

The need for budgetary restraint has in recent years been the main focus of the policy debate in Portugal. In this context, an unavoidable fact is that public wages are a large and growing share of the public budget, having increased from $29.9 \%$ of public spending in 1996 to $33.5 \%$ in 2002 or from $13.7 \%$ of the GDP in 1996 to $15.4 \%$ in 2002 [see DGEP (2006)]. The perception is that this situation is directly related to a dramatic increase in public employment and, accordingly, hiring freezes have been a central feature of all attempts to achieve fiscal consolidation.

A complicating factor, however, is that hiring freezes may not be enough to control the expansion of the public wage bill. This is because public careers are characterized by a system of automatic progressions within each rank and discretionary promotions to higher ranks, both of which lead to higher wages. Therefore the public wage bill has a tendency to increase even in the presence of constant employment. This is what we call the wage drift.

This study estimates the wage drift for the career of university professors. Since progressions and promotions imply different wage changes, a logit model is estimated to determine the characteristics of employees that are significant in determining the mode of career advancement. Sample information and the econometric results are used to estimate the employment distribution and the wage bill in different years under the assumption of constant employment, and thereby, to estimate the wage drift.

\section{The Data}

The IGDAP Census provides descriptive statistics for Portuguese public sector employees in 1999. It includes one hundred and fifty thousand individual records with information on gender, education, career, seniority, rank, level, date of entry into career, date of entry into rank, date of entry into level, wages, etc [see Centeno and Pereira (2005) for a detailed description of this data.]

This census includes 3069 entries for university professors, which corresponds to $2.1 \%$ of public employment and $4.8 \%$ of public wages. Table 1 presents the 1999 employment distribution within five ranks, each with up to four different wage levels, and the respective wage index based on an entry-level wage of $100=1,273$ euros. The wage bill in 1999 was 1,821 million euros, and is calculated as the sum across all cells of the product of the number of individuals within each cell, the corresponding wage index, and the entry-level wage.

\section{Estimating the mode of career advancement}

Our calculation of the wage drift is based on the estimate of the wage bill for several years under the assumption of a fixed sample population. The wage bill depends on the employment distribution over the different career positions. Furthermore, knowing this distribution at a specific time and given the rules of progression and promotion we can infer where each employee must have been previously. We can, then, infer the employment distribution and calculate the wage bill at that earlier time. 
Table 1: 1999 employment and wage distribution

\begin{tabular}{|c|c|c|c|c|c|}
\hline Level & 1 & 2 & 3 & 4 & Total \\
\hline \multicolumn{6}{|l|}{ Full Professor } \\
\hline Number & 100 & 123 & 77 & 323 & 623 \\
\hline Wage index & 285 & 300 & 310 & 330 & \\
\hline \multicolumn{6}{|c|}{ Distinguished Associate Professor } \\
\hline Number & 14 & 28 & 79 & 82 & 203 \\
\hline Wage index & 245 & 255 & 265 & 285 & \\
\hline \multicolumn{6}{|l|}{ Associate Professor } \\
\hline Number & 46 & 128 & 259 & 303 & 736 \\
\hline Wage index & 220 & 230 & 250 & 260 & \\
\hline \multicolumn{6}{|l|}{ Assistant Professor } \\
\hline Number & 212 & 265 & 219 & 259 & 955 \\
\hline Wage index & 195 & 210 & 230 & 245 & \\
\hline \multicolumn{6}{|l|}{ Teaching Assistant } \\
\hline Number & 120 & 96 & 336 & & 552 \\
\hline Wage index & 135 & 140 & 150 & & \\
\hline Total & & & & & 3069 \\
\hline
\end{tabular}

We need to start by considering the rules of progression and promotion. This distinction is critical since they have different implications for the evolution of wages. Public regulations require that no individual spend more than three years in a given career position. Every three years the individual may progress through the career or may be promoted to the lowest level of the next rank that is consistent with a wage increase of a minimum of 15 index points. Additionally, some positions, such as the entry level in each rank, require promotional entry. Finally, upon reaching the highest level in each rank the only way out is promotion, therefore individuals may spend more than three years in these levels.

There are seven career positions into which both promotion and progression are possible: Full Professor - level 2; Distinguished Associate Professor - levels 2, 3, and 4; and Associate Professor levels 2, 3, and 4. A logit analysis is used to identify the characteristics that are significant in determining the mode of advancement. The analysis provides the odds of having been promoted into the current career position.

The endogenous variable is binary and captures promotion or progression into the current position. The mode of advancement can be determined from the data by comparing the date of entry into the level and the date of entry into the rank. Several explanatory variables are used. Years of service, capture seniority and work experience, while years from entry until promotion to the current rank indicate the rate of progress within the career. We also consider the current level, gender, and education.

The regressions show a very good fit with pseudo- $\mathrm{R}^{2}$ values always over 0.84 . In all cases years of service, years until promotion, and the current level are significant at the $1 \%$ level. The coefficients for years of service are consistently negative indicating that at earlier career stages promotion is more likely to occur. In addition, it indicates that performance dominates work experience and seniority as a determinant of promotion, which supports a view of meritocracy in academia. The coefficient for years until promotion is negative as well. Individuals who have been in their career for longer before reaching their present rank are more likely to progress.

These findings are consistent with the evidence in the literature. Da Silva and Van der Klaauw (2006), for example, assess the importance of work experience on promotions in the private sector. They conclude that there is serial correlation in wage increases and that momentum is, therefore, a predictor of 
promotion. In turn, Baker, Gibbs and Holmstrom (1994) analyze intra-firm personnel data and find that wage changes are serially correlated and that workers who receive large wage increases early in their stay at one level of the job ladder are promoted quickly to the next level. In addition, McCue (1996) also in the context of intra-firm mobility finds that most promotions occur early in the career and that mobility declines both with time in position and with experience.

Finally, significance tests show that gender and education are not significant. Education levels within this career are rather uniform and, therefore, we would not expect this variable to be significant. In addition, gender has little effect on the mode of career advancement. While this is not surprising in the case of university professors the opposite seems to be true in other cases. Indeed, Centeno and Pereira (2005) show evidence of a glass ceiling for women in the public sector in Portugal while Vidal and Leaver (2006) find gender to be important in senior judicial appointments in England and Wales.

\section{Estimating the evolution of the employment distribution}

Given the rules of career advancement and our empirical finding that years of service and years until promotion are the most significant factors in determining the mode of advancement into the current position, we are in position of estimating the employment distribution in earlier years. The basic information from the 1999 census is presented in Table 2.

Table 2: 1999 sample averages

\begin{tabular}{|c|c|c|c|c|}
\hline Level & 1 & 2 & 3 & 4 \\
\hline \multicolumn{5}{|c|}{ Years of service } \\
\hline Full Professor & 20.42 & 20.67 & 22.61 & 28.85 \\
\hline Distinguished Associate Professor & 14.64 & 17.14 & 18.68 & 18.36 \\
\hline Associate Professor & 12.57 & 15.86 & 18.70 & 22.54 \\
\hline Assistant Professor & 12.01 & 15.24 & 16.05 & 20.58 \\
\hline Teaching Assistant & 6.09 & 6.72 & 13.14 & \\
\hline \multicolumn{5}{|c|}{ Years until promotion } \\
\hline Full Professor & 18.26 & 17.20 & 16.48 & 12.98 \\
\hline Distinguished Associate Professor & 14.64 & 17.14 & 18.68 & 18.37 \\
\hline Associate Professor & 11.35 & 13.34 & 14.77 & 12.76 \\
\hline Assistant Professor & 10.4 & 10.87 & 9.18 & 9.47 \\
\hline Teaching Assistant & 2.18 & 2.01 & 3.62 & - \\
\hline
\end{tabular}

Since career advancement rules dictate that all individuals must advance within a career every 3 years, the year of 1996 was chosen as the first comparison estimate, for by this year the population must have completely shifted cells, except for individuals who remain in the highest level of each rank. The employment distribution in 1996 is presented in Table 4 and is determined from the 1999 data using the probabilities of promotion estimated for 1999 and presented in Table 3. 
Table 3: Probabilities of having been promoted given cell position in 1999

\begin{tabular}{|c|c|c|c|c|}
\hline Level & 1 & 2 & 3 & 4 \\
\hline Full Professor & 1.000 & 0.301 & 0.000 & 0.000 \\
\hline Distinguished Associate Professor & 1.000 & 0.536 & 0.443 & 0.207 \\
\hline Associate Professor & 1.000 & 0.617 & 0.409 & 0.089 \\
\hline Assistant Professor & 1.000 & 0.000 & 0.000 & 0.000 \\
\hline Teaching Assistant & 1.000 & 0.000 & 0.000 & - \\
\hline
\end{tabular}

Table 4: 1996 estimated employment distribution

\begin{tabular}{|c|c|c|c|c|c|}
\hline Level & 1 & 2 & 3 & 4 & Total \\
\hline Full Professor & 94 & 77 & 263 & 60 & 494 \\
\hline Distinguished Associate Professor & 46 & 75 & 96 & 37 & 254 \\
\hline Associate Professor & 58 & 174 & 236 & 92 & 560 \\
\hline Assistant Professor & 320 & 298 & 365 & 27 & 1010 \\
\hline Teaching Assistant & 283 & 332 & 138 & - & 753 \\
\hline Total & & & & & 3069 \\
\hline
\end{tabular}

The employment distribution for 1993 is estimated similarly. The probabilities of promotion for the seven relevant cells are determined from the regressions results, by using the sample average minus three years. This yields the probabilities of the same individuals at a younger age having been promoted into a specific career position in 1996. The probabilities of promotion are presented in Table 5 and the corresponding 1993 employment distribution in Table 6.

From the estimated employment distributions for 1996 and 1993 and the wage index information in Table 1 we calculate the wage bill for 1996 and 1993. We find that the wage bills for 1993 and 1996 are $85.6 \%$ and $93.0 \%$, respectively, of the 1999 wage bill. This represents a $14.4 \%$ increase over the $6-$ year period, which corresponds to an average annual growth rate of $2.6 \%$.

Table 5: Probabilities of having been promoted given cell position in 1996

\begin{tabular}{|lllll|}
\hline \multicolumn{1}{|c}{ Level } & $\mathbf{1}$ & $\mathbf{2}$ & $\mathbf{3}$ & $\mathbf{4}$ \\
\hline Fank & & & & 0.000 \\
Distinguished Associate Professor & 1.000 & 0.240 & 0.000 & 0.141 \\
Associate Professor & 1.000 & 0.236 & 0.273 & 0.074 \\
Assistant Professor & 1.000 & 0.606 & 0.112 & 0.000 \\
Teaching Assistant & 1.000 & 0.000 & 0.000 & - \\
\hline
\end{tabular}


Table 6: 1993 estimated employment distribution

\begin{tabular}{|c|c|c|c|c|c|}
\hline Level & 1 & 2 & 3 & 4 & Total \\
\hline Full Professor & 55 & 263 & 60 & 0 & 378 \\
\hline Distinguished Associate Professor & 62 & 85 & 59 & 22 & 228 \\
\hline Associate Professor & 79 & 234 & 124 & 9 & 446 \\
\hline Assistant Professor & 356 & 484 & 97 & 9 & 946 \\
\hline Teaching Assistant & 721 & 244 & 106 & & 1071 \\
\hline Total & & & & & 3069 \\
\hline
\end{tabular}

\section{Concluding Remarks}

Given the serious public budgetary situation in Portugal and the size of public sector employment, hiring freezes have been the instrument of choice to achieve fiscal consolidation. A complicating factor is that public career advancement is regulated by automatic progressions and discretionary promotions which carry with them wage increases and, therefore, increase the wage bill even in the presence of constant employment. In this paper we estimate this wage drift effect for university professors to be $2.6 \%$ a year. If we extrapolate this pattern to the overall public employment universe, and considering that the average GDP growth in recent years is just $1.1 \%$, one would expect the public wage bill to increase as a share of the GDP even with a hiring freeze, a pattern that is corroborated by the data. Therefore, hiring freezes may be insufficient to stem the tide of growth in the public wage bill and a reform of the career advancement rules may be unavoidable.

\section{REFERENCES}

Baker, G., M. Gibbs and B. Holmstrom (1994). "The Internal Economics of the Firm: Evidence from Personnel Data," Quarterly Journal of Economics 109(4), 881-919.

Centeno, M. and M. Pereira (2005). "Wage Determination in General Government in Portugal," Economic Bulletin - Bank of Portugal, Vol. 11 (3), 73-88

Da Silva, A. and B. van der Klaauw (2006). "Wage Dynamics and Promotions Inside and Between Firms," mimeo.

DGEP (2006). Portuguese Economy - Statistical Annex, Ministério das Finanças, Portugal.

Gibbons, R. and M. Waldman (1999). "A Theory of Wage and Promotion Dynamics Inside Firms," Quarterly Journal of Economics 114, 1321-58.

McCue, K. (1996). "Promotions and Wage Growth,” Journal of Labor Economics 14, 175-209.

Vidal, J. and C. Leaver (2006). An Economic Analysis of Judicial Diversity: Judicial Promotions. Oxford University Press. 